\title{
The Treatment of Ledipasvir/Sofosbuvir in Patients with Chronic Hepatitis C Virus: The Results of Five-year Follow-up
}

\section{Kronik Hepatit C Virüslü Hastalarda Ledipasvir/Sofosbuvir Tedavisi: Beș Yıllık Takip Sonuçları}

\author{
๑ ( Murat Pekgöz¹, ๑ Nevin Ince² \\ ${ }^{1}$ Bolu Izzet Baysal State Hospital, Clinic of Gastroenterology, Bolu, Turkey \\ 2Düzce University Faculty of Medicine, Department of Clinical Microbiology and Infectious Diseases, Düzce, Turkey
}

\begin{abstract}
Objectives: Chronic hepatitis C virus (HCV) is a fundamental worldwide health challenge. We assessed the treatment outcomes of ledipasvir (LDV) and sofosbuvir (SOF) with and without ribavirin (RBV) for 12 and 24 weeks in pre-treated and treatment-naive patients with chronic HCV.

Materials and Methods: Totally 65 patients were included in the present study. Patients were divided in two groups. In the first group, LDV and SOF with RBV were administered to 12 patients for 12 weeks. In the second group, LDV and SOF without RBV were administered to 53 patients for 24 weeks.

Results: Sustained virological response (SVR) rates were 100\% for the both groups included in the study. The adverse events were weakness $(15.39 \%)$, pruritus $(6.15 \%)$, myalgia $(4.62 \%)$ nausea $(3.08 \%)$, dry mouth $(1.54 \%)$ and anorexia $(1.54 \%)$ in all patients. HCV-RNA was also negative in all patients 48 weeks after the beginning of the treatment. At the end of the fifth year of treatment, all the patients still had SVR and no recurrence was detected. Conclusion: In the treatment of patients with chronic HCV, LDV and SOF with and without RBV were highly effective. SVR rate of $100 \%$ was achieved in all pre-treated or treatment naive patients with or without cirrhosis regardless of genotype of HCV.

Keywords: Chronic hepatitis C virus, direct-acting antiviral agents, sofosbuvir, ledipasvir
\end{abstract}

ÖZ

Amaç: Kronik hepatit $\mathrm{C}$ virüsü $(\mathrm{HCV})$, dünya çapında temel bir sağlık sorunudur. Bu çalışmamızda tedavi naif ve deneyimli kronik HCV'li hastalarda 12 ve 24 hafta boyunca ribavirin (RBV) içeren ve içermeyen ledipasvir (LDV) ve sofosbuvir (SOF) tedavi sonuçlarını değerlendirdik.

Gereç ve Yöntemler: Toplamda 65 hasta çalışmaya dahil edildi. Hastalar iki gruba ayrıldı. Birinci grupta 12 hastaya 12 hafta boyunca LDV ve SOF ile RBV verildi. Ikinci grupta 53 hastaya 24 hafta boyunca LDV ve SOF uygulandı.

Bulgular: Her iki grupta da kalıc viral yanıt oranı (SVR) \%100 bulundu. Tüm hastalar içinde yan etki olarak halsizlik $(\% 15,39)$, kaşıntı $(\% 6,15)$, kas ağıısı $(\% 4,62)$, bulantı $(\% 3,08)$, ağız kuruluğu $(\% 1,54)$ ve iştahsızlık $(\% 1,54)$ görüldü. Tedavinin başlangıcından 48 hafta sonra tüm hastalarda HCV-RNA hala negatif idi. Beşinci yllın sonunda tüm hastalarda SVR mevcuttu ve nüks saptanmadı.

Sonuç: RBV'li ve RBV'siz LDV ve SOF tedavisi, kronik HCV'li hastaların tedavisinde oldukça etkindir. HCV genotipinden bağımsız olarak, sirozu olan veya olmayan tüm tedavi deneyimli ve naif hastalarda \%100 SVR oranlarına ulaşılmıştır.

Anahtar Kelimeler: Kronik hepatit C virüs, direkt etkili antiviral ajanlar, sofosbuvir, ledipasvir 


\section{Introduction}

Viral hepatitis has a major global health challenge, affecting 71 million with chronic hepatitis $\mathrm{C}$ virus $(\mathrm{HCV})$ infection. It is a root cause of cirrhosis and liver cancer, causing about 1.4 million deaths annually. HCV can be eliminated without treatment within six month in approximately $15-45 \%$ of infected people, whereas it can evolve into chronic infection for the remaining 55-85\% of infected people (1). HCV is categorized into 6 genotypes (1-6) with various subtypes based on genetic variations (2). Globally, genotype 1 is the most common type of $\mathrm{HCV}$ with the rest of the genotypes accounting for more than half of all HCV infections (1).

The sustained virological response (SVR) rate was 40-50\% with standard pegylated-interferon (IFN) and ribavirin (RBV) treatment, and the rate increased to $60-80 \%$ with the addition of protease inhibitors [telaprevir (TVR)/boceprevir (BOC)] to the treatment in chronic HCV (3). Revolutionary developments have been achieved in the treatment of $\mathrm{HCV}$ after the onset of IFN-free regimens comprising of oral direct-acting antiviral (DAA) agents. Among the treatment options, the one with the highest SVR rate and the least adverse events in the minimum treatment period can be adopted as the best option (4). Literature review showed that DAA regimens can provide evident better antiviral efficacy with remarkable SVR rates exceeding $90-95 \%(5,6,7,8,9,10)$.

Treatment with sofosbuvir/ledipasvir (SOF/LDV) introduced very potent, well-tolerated, influential and non-IFN-based antiviral regimens for $\mathrm{HCV}$ infection applicable for the first time (11). SOF is a uridine nucleotide analogue inhibitor of the HCV-NS5B polymerase (12) and LDV is an inhibitor of the HCV-encoded NS5A protein (13). The combination of SOF/LDV with or without RBV in the treatment of $\mathrm{HCV}$ infection has improved the impressively high SVR rates up to $95 \%$, even reaching $100 \%$ in some cases $(4,14,15$, $16,17,18,19,20,21,22,23)$. According to its high level genetic barrier, the development of resistance to it is at low. Thus, reaccurance of the disease is almost not observed. Additionally, due to its IFNfree form, treatment with SOF/LDV caused less adverse events than IFN based regimens $(18,19)$. A fixed-dose combination tablet consisting SOF united with LDV has been adopted in European Union, United States and other regions all over the world for the treatment of HCV infection (6) which has been adopted by U.S. Food and Drug Administration (24). This combination regimen is recommended by clinical practice guidelines in the European Union and the United States for the treatment-experienced and treatment-naive patients infected by HCV virus (25).

The fixed-dose combination of SOF/LDV has been used for the treatment of HCV recently. The objective of this study was to compare and assess the real-world effectiveness, safetyand longterm outcomesof SOF/LDV with and without RBV in treatment of patients with HCV.

\section{Materials and Methods}

\section{Patients}

A total of 65 adult patients were enrolled into the current study. All patients were diagnosed, followed and treated at Düzce University Faculty of Medicine and Bolu State Hospital in Turkey from 2015 to 2021. Treatment-experienced or treatment-naïve patients over 18 years of age with chronic HCV infection, with or without cirrhosis, were included in this study. There was no exclusion criteria based on body mass index (BMI) and age. Liverbiopsy was conducted to determine the presence of cirrhosis for twenty-seven patients according to the Ishak score of 5 or 6 (on a scale of 0 to 6 in which higher scores indicate a greater degree of fibrosis). Treatment-experienced patients had previously received combinations of pegile-IFN + RBV \pm TVR/BOC, but infection relapsed in all of treatment-experienced patients.

\section{Study Design}

This study was an open-label, multi-centre, real-world study and conducted at Düzce University Hospital and Bolu State Hospital in Turkey. All patients orally received a fixed-dose combination tablet comprising of $400 \mathrm{mg}$ of SOF and $90 \mathrm{mg}$ of LDV with or without RBV once daily. Patients below and equal to $75 \mathrm{~kg}$ were treated with $1000 \mathrm{mg}$ RBV and those over $75 \mathrm{~kg}$ were treated with 1200 mg RBV. Patients were divided into two groups. One group with 53 patients received SOF/LDV for 24 weeks and the other group with 12 patients received SOF/LDV with RBV for 12 weeks.

Laboratory parameters and adverse events were measured, recorded, and assessed before treatment and 2, 4, 12, 24, 36, 48 weeks and 60 monthsafter the beginning of the treatment. Patients were examined in detail and questioned about the possible adverse events of the treatment during the follow-up. The Child-Pugh score system was adopted to determine clinical status on cirrhotic patients. HCV diagnosis was determined as a positive test for anti-HCV antibodies validated by a positive HCV viral load.

Samples for laboratory parameters were acquired during the procedural examination and none were taken during renal crisis, acute liver or under any acute illness. HCV-RNA levels were measured by real-time polymerase chain reaction according to standard methods.

\section{Study Oversight}

The study was approved by Ethics Committee Düzce University (approval number: 2019/103, date: 15.05.2019). The research was performed in accordance with the principles of Good Clinical Practice guidelines, the Declaration of Helsinki, and local regulatory requirements. Written informed consent was obtained from each patient. Demographic and clinical characteristics of all patients were recorded, and concomitant treatments clinical assessments and other medical decisions were applied at the discretion in accordance with standard clinical practice. The authors obtained and edited the data, followed up the all processes of the study and conducted the statistical analyses. Data confidentiality was maintained by the authors.

\section{Study Assessments}

Measurement of laboratory data on HCV-RNA level, alanine aminotransferase (ALT), aspartate aminotransferase (AST), and serum biomarkers such as bilirubin, albumin, urea (URE), creatinine, hemoglobin $(\mathrm{Hb})$, total leukocyte [white blood cell-(WBC)] platelets count (PLT) and international normalised ratio were included in follow up assessments. All adverse events were recorded.

\section{Study Endpoints}

The primary efficacy endpoint was the proportion of the patients achieving SVR at 12 weeks (SVR12). SVR12 was defined as the rate of patients with HCV-RNA concentration in serum 
lower than $25 \mathrm{IU} / \mathrm{mL} 12$ weeks after the completion of treatment. The primary safety endpoint was any adverse event leading to discontinuation of the treatment. The secondary efficacy endpoint was the proportion of the patients achieving SVR at 60 months.

\section{Statistical Analysis}

The clinical and demographic characteristics of patients were summarized by using mean, range, standard deviation, frequency (count) and relative frequency (percentage). The two groups were compared by conducting the non-parametric Mann-Whitney for the continuous variables and the chi-square test for the categorical variables, since the quantitative variables were non-normally distributed. Serial measurements for pretreatment and end of treatment were compared by performing the Wilcoxon signed-rank test. Statistically significance was considered for $p$-values less than 0.05 and the confidence intervals set at the 95\% level. The SPSS version 25 was used to conducted the statistical analysis.

\section{Results}

\section{Baseline Characteristics}

Clinical and demographic characteristics of the patients are shown in Table 1 for both groups. Patients were divided into two groups according to the treatment regiments they received. Twelve patients in the first group received LDV and SOF with RBV and 53 patients in the second group received LDV/SOF. The mean age of the patients was 56.4 in the first group, 65.2 in the second group and 63.5 for the overall study population. The range of patients's age were between $22-71$ and $25-86$ in those groups, respectively. There were 7 (10.77\%) females in the first group and 28 (43.08\%) females in the second group. The number of males in the groups were $5(7.69 \%)$ and 25 (38.46\%), respectively. Most of the patients were infected by HCV genotype 1b, with 7 (10.77\%) patients in the first group infected with HCV genotype $1 \mathrm{~b}$ and 50 patients $(76,92 \%)$ in the second group infected with HCV genotype $1 \mathrm{~b}$. In

\begin{tabular}{|c|c|c|c|c|}
\hline Characteristic & 1. Group LDV/SOF + RBV $(n=12)$ & 2. Group LDV/SOF $(n=53)$ & Total & p-value \\
\hline Age & - & - & - & 0.071 \\
\hline Range & $22-71$ & $25-86$ & $22-86$ & - \\
\hline Gender & - & - & - & 0.730 \\
\hline Male & $5(7.69 \%)$ & $25(38.46 \%)$ & $30(46.15 \%)$ & - \\
\hline Genotype & - & - & - & 0.001 \\
\hline $1 \mathrm{a}$ & $1(1.54 \%)$ & $3(4.62 \%)$ & $4(6.15 \%)$ & - \\
\hline $1 \mathrm{~b}$ & $7(10.77 \%)$ & $50(76.92 \%)$ & $57(87.69 \%)$ & - \\
\hline $2 a$ & $2(3.08 \%)$ & - & $2(3.08 \%)$ & - \\
\hline 0 & - & $3(4.62 \%)$ & $3(4.62 \%)$ & - \\
\hline 1 & $2(3.08 \%)$ & $1(1.54 \%)$ & $3(4.62 \%)$ & - \\
\hline 2 & - & $3(4.62 \%)$ & $3(4.62 \%)$ & - \\
\hline 3 & $2(3.08 \%)$ & $6(9.23 \%)$ & $8(12.31 \%)$ & - \\
\hline 4 & - & $3(4.62 \%)$ & $3(4.62 \%)$ & - \\
\hline 5 & - & $6(9.23 \%)$ & $6(9.23 \%)$ & - \\
\hline 6 & - & $1(1.54 \%)$ & $1(1.54 \%)$ & - \\
\hline Cirrhosis & & 10 & $10(15.39 \%)$ & - \\
\hline Previous HCV treatment(s) & - & - & - & 0.553 \\
\hline Viral load (IU/mL) & $862.064 \pm 1.037 .904$ & $1.797 .026 \pm 3.725 .150$ & $1.624 .418 \pm 3.412 .528$ & - \\
\hline
\end{tabular}


total, 41 patients had received treatment with IFN + RBV regimen and 5 patients had received treatment with TVR or BOC regimen prior to this study. Nineteen patients were treatment-naive in total. The mean baseline HCV-RNA was $5.50 \log _{10} \mathrm{IU} / \mathrm{mL}$ in the first group and $5.66 \log _{10} \mathrm{IU} / \mathrm{mL}$ in the second group. Only twenty-seven of the patients received liver biopsy prior to the treatment. Results of the liver biopsies showed that nine patients had minimal or no fibrosis (Ishak F0, 1, 2), eight patients had portal fibrosis (Ishak F3), three patient had bridging fibrosis (Ishak F4) and seven patients had cirrhosis (Ishak F5, 6). There were only 10 (15.39\%) patients with cirrhosis in the second group. Decompensated liver failure, such as ascites or jaundice, were not found in any of patients. There was no significant difference between the two groups regarding their gender, fibrosis cases, cirrhosis cases, previous HCV treatment, and baseline HCV-RNA levels.

The differences between two groups regarding mean age were found to be statistically insignificant $(p=0.07)$. There were more patients with HCV 1a genotype and 1b genotype in the second group than the first group. The results of the measurements for the laboratory parameters are shown in Table 2. Reduction in ALT and AST for the both group, increase in WBC for the second group, reduction in $\mathrm{Hb}$ for the first group, increment in PLT for the both groups, and increment in URE for the second group were found to be statistically significant.

In both groups, ALT and AST values decreased significantly at 12 weeks compared with pretreatment. The mean AST and ALT levels, which were 2-3 times higher before treatment, returned to normal levels at the end of the treatment. Treatment-induced anemia was observed in the RBV group $(p=0.015)$, whereas $\mathrm{Hb}$ was not decreased in the LDV + SOF group $(p=0.245)$. Platelet levels were significantly increased in both groups after treatment (respectively $p=0.028$ and $p=0.027$ ). The increase in URE values in LDV + SOF group was not accompanied by elevation of creatine.

\section{Efficacy}

HCV-RNA levels in the treatment weeks and rates of SVR are presented in Figure 1. At the end of the fourth treatment week, HCV-RNA levels for 11 (91.67\%) of 12 patients in the first group (LDV/SOF + RBV) and 50 (94.34\%) of 53 patients in the second group (LDV/SOF) were not able to be detected. At week 12 of treatment, virologic suppression was achieved on all patients in both groups. All patients in both groups, including the 10 with compensated cirrhosis at baseline, had sustained virologic response 12 weeks after the end of treatment. In addition, HCVRNA was negative in all patients 48 weeks after starting treatment. No significant differences were observed between the two groups, since all patients achieved SVR after the treatment. Also all the patients achieved SVR 60 months after the end of treatment. None of them had relapse.

\section{Safety}

The adverse events experienced by the patients are summarized in Table 3. None of the patients experienced any serious adverse events. At least one adverse event was experienced by $16.9 \%$ of the patients during the study. The adverse events were weakness $(15.39 \%)$, pruritus $(6.15 \%)$, myalgia (4.62\%), nausea $(3.08 \%)$, dry mouth (1.54\%) and anorexia (1.54\%). Myalgia $(p=0.028)$ and anorexia $(p=0.034)$ were found to be more common in the first group and statistically significant. Weakness effects were more common in the second group and can be accepted statistically

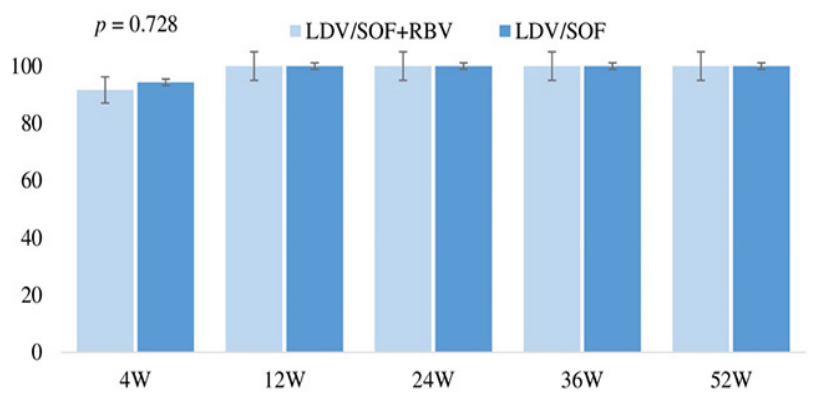

Figure 1. Rates of sustained virological responses. Error bars shows 95\% confidence intervals

LDV: Ledipasvir; SOF: Sofosbuvir, RBV: Ribavirin, W: week

\begin{tabular}{|l|l|l|l|l|l|l|}
\hline \multicolumn{2}{|l|}{ Table 2. Laboratory data measurements } \\
\hline
\end{tabular}




\begin{tabular}{|l|l|l|l|l|}
\hline Table 3. Adverse events & 1. Group LDV/SOF + RBV $(\mathbf{n}=\mathbf{1 2})$ & 2. Group LDV/SOF $(\mathbf{n}=53)$ & Total & -value \\
\hline Characteristic & $8(12.31 \%)$ & $46(70.77 \%)$ & $54(83.08 \%)$ & 0.093 \\
\hline None & $4(6.15 \%)$ & $6(9.23 \%)$ & $10(15.39 \%)$ & 0.056 \\
\hline Weakness & $1(1.54 \%)$ & $3(4.62 \%)$ & $4(6.15 \%)$ & 0.728 \\
\hline Pruritus & $2(3.08 \%)$ & $1(1.54 \%)$ & $3(4.62 \%)$ & $\mathbf{0 . 0 2 8}$ \\
\hline Myalgia & $1(1.54 \%)$ & $1(1.54 \%)$ & $2(3.08 \%)$ & 0.243 \\
\hline Nausea & - & $1(1.54 \%)$ & $1(1.54 \%)$ & - \\
\hline Dry mouth & $1(1.54 \%)$ & - & $1(1.54 \%)$ \\
\hline Anorexia & & & - \\
\hline LDV: Ledipasvir, SOF: Sofosbuvir, RBV: Ribavirin & & & \\
\hline
\end{tabular}

significant $(p=0.056)$. Discontinuation of the treatment due to adverse events did not occur for any of the patients.

\section{Discussion}

The World Health Assembly declared the elimination of viral hepatitis as a public health threat by 2030 in the Global Health Sector Strategy through reducing its incidence by $90 \%$ and reducing its mortality by $65 \%$. The global prevalence of $\mathrm{HCV}$ was $1 \%$ in 2015 , ranging between $0.5 \%$ (South-East Asia Region) and 2.3\% (Eastern Mediterranean Region) depending on the regions. Chronic HCV is considered to be one of the major causes of hepatocellular carcinoma and liver cirrhosis (1). Therefore, every patient with positive HCV-RNA should be treated. There was a complete change in the treatment of HCV with DAAs, which were first introduced in 2011. Nowadays, INF-free therapies are being used in chronic HCV. INF-free therapies are superior in terms of both efficacy and safety when compared to previous therapies.

The aim of the present study was to evaluate the response of patients infected with chronic HCV to treatment with a fixed-dose combination of LDV/SOF with RBV for 12 weeks treatment period or without RBV for 24-week treatment period. The response rates and SVR were compared for two groups received two different regimens. The results of this study showed that a fixed-dose combination of LDV/SOF with RBV during 12 weeks and without RBV during 24 weeks were highly effective treatment regimens for HCV. In the phase studies of LDV + SOF, up to $99 \%$ sustained viral response was obtained in different patient groups and for different protocols $(18,19,20)$.

Our results are consistent with the recent studies concluded $100 \%$ SVR rates of treatment with LDV/SOF $(16,17,21,22)$. Shousha et al. (17) evaluated the safety and efficacy of generic SOF/LDV for 8 and 12 weeks in 40 naive non-cirrhotic patients with HCV genotype 4 . They revealed that 8 weeks of treatment with generic SOF/LDV had SVR12 rates of $100 \%$ and SVR12 rates of $95 \%$ with 12 weeks of the same regimen.

Liu et al. (16) enrolled 111 patients infected with HCV virus along with HBV infection to their open-label, multicenter and phase 3b study. They administrated a fixed-dose combination of LDV/ SOF to all patients, once daily for 12 weeks. They concluded that the combination of LDV/SOF lead to an SVR12 rate of $100 \%$ of patients with $\mathrm{HCV}$ infection who were co-infected with HBV. Shiha et al. (21) assessed the efficacy and safety of LDV/SOF with and without RBV for 8 and 12 weeks in 255 Egyptian patients infected with HCV virus genotype 4 . The results of this study indicated that
SVR12 rates were over $90 \%$ for all groups. SVR rates of $100 \%$ were only found among INF-experienced patients who received 2 weeks of LDV/SOF with RBV.

Mizokami et al. (22) administrated either LDV (90 mg) and SOF (400 mg) or LDV/SOF and RBV orally to 341 patients infected with HCV virus genotype $1 \mathrm{a}$ and $1 \mathrm{~b}$, once daily for 12 weeks, in their randomized, open-label study. SVR12 rates of $100 \%$ were achieved in all 171 patients who received LDV/SOF and SVR12 rates of $98 \%$ were achieved in patients who received LDV/SOF with RBV.

Many parameters such as age, sex, cirrhosis, response to previous treatments, BMI, and HCV-RNA levels can affect the success of treatment in INF-based treatments. In our study, all cirrhotic patients had SVR12. 81\% of the patients had high viral load ( $\geq 5 \log _{10} \mathrm{IU} / \mathrm{mL}$ ) and treatment was successful in all of them. There was no difference in response to treatment between naive and experienced patients.

Studies on long-term results of SOF-based DAA therapies generally have a short follow-up period. The number of studies with long-term follow-up results is not very high. Some statistical modeling studies show that long-term results are effective and there is a decrease in HCV-related mortality and advanced liver disease. In addition, the treatment was found to be costeffective $(26,27)$. Long-term sustained viral response was observed in the mean 96-week follow-up of 62 patients who had relapsed after liver transplantation and were treated with DAA (28). In the 24-month follow-up period of 120 patients with liver transplantation, it was determined that the treatment was effective and there was improvement in liver tests (29). SOF/LDV therapy is effective and tolerable also in patients with advanced liver disease to $\mathrm{HCV}$. In a study in which 200 patients with advanced liver disease due to HCV were followed for an average of 22 months, SOF/LDV treatment was found to be effective and tolerable. With eradication of $\mathrm{HCV}$, improvement in liver functions was detected and the risk of developing new hepatocellular carcinoma was reduced (30). Although the number of patients was small in our study, the followup period was quite long, such as 60 months. At the end of the follow-up period, improvement in liver function tests was observed in all patients. Decompensation and hepatocellular carcinoma did not develop in any of the cirrhotic patients. No patient died.

INF-based treatments were discontinued because of serious adverse effects. This in turn reduced the success rate of the treatment. In our study, no serious adverse effects were observed in any of the patients. The two treatment regimens used in our study were safe and well tolerated. There was no discontinuation caused by any adverse effect. The most common adverse effects 
were weakness, rash, myalgia and nausea. One patient had dry mouth and one patient had insomnia. Anemia was observed in the group receiving RBV ( $p=0.015)$ but not in the other group. The adverse effects seen in our study were similar with to those seen in the literature and phase studies $(18,19,20,21,22)$.

\section{Study Limitations}

There were limitations to the present study. First, the relatively small sample size of the study might affect significance of the statistical tests. Second, the two study groups were not randomized equally. Third, all of the patients infected with HCV virus were selected from justtwohospital and therefore, selection bias could not be avoided.

\section{Conclusion}

LDV and SOF regimen is a very effective and reliable treatment for controlling chronic HCV infection in all patient groups. HCV eradication may be possible with systematic and effective treatment of chronic HCV patients.

\section{Ethics}

Ethics Committee Approval: The study was approved by Ethics Committee Düzce University (approval number: 2019/103, date: 15.05.2019).

Informed Consent: Written informed consent was obtained from each patient.

Peer-review: Externally peer-reviewed.

\section{Authorship Contributions}

Concept: M.P., N.I., Design: M.P., N.I., Data Collection or Processing: M.P., N.I., Analysis or Interpretation: M.P., N.I., Literature Search: M.P., N.I., Writing: M.P., N.I.

Conflict of Interest: The authors of this article declare that they have no conflict of interest.

Financial Disclosure: The authors declare that this study has not received any financial support.

\section{References}

1. World Health Organization. Guidelines for the care and treatment of persons diagnosed with chronic hepatitis c virus infection, date of access: July 2018. https://www.who.int/hepatitis/publications/ hepatitis-c-guidelines-2018/en/

2. Li DK, Chung RT. Overview of direct-acting antiviral drugs and drug resistance of hepatitis C virus. In: Law M. (eds), Hepatitis C Virus Protocols. New York: Springer Science + Business Media; 2019; p. 3-32.

3. Pekgöz M, Gürel S, Kiyici M, Gülten M, Dolar E, Nak SG. Retreatment of chronic hepatitis $\mathrm{C}$ infection with telaprevir: Turkey experience. Acta Gastroenterol Belg. 2016;79:18-22.

4. Rezaee-Zavareh MS, Hesamizadeh K, Behnava B, Alavian SM, Gholami-fesharaki M, Sharafi H. Combination of ledipasvir and sofosbuvir for treatment of hepatitis $C$ virus genotype 1 infection: Systematic review and meta-analysis. Ann Hepatol. 2017;16:188197.

5. Scott LJ. Ledipasvir/sofosbuvir: A review in chronic hepatitis C Drugs. 2018;78:245-256

6. German P, Mathias A, Brainard D, Kearney BP. Clinical pharmacokinetics and pharmacodynamics of ledipasvir/sofosbuvir, a fixed-dose combination tablet for the treatment of hepatitis C. Clin Pharmacokinet. 2016:55:1337-1351.

7. Khaliq S, Raza SM. Current status of direct acting antiviral agents against hepatitis $\mathrm{C}$ virus infection in Pakistan. Medicina (Kaunas). 2018;54:80.

8. Siddique MS, Shoaib S, Saad A, lqbal HJ, Durrani N. Rapid virological\&end treatment response of patients treated with sofosbuvir in chronic hepatitis C. Pak J Med Sci. 2017;33:813-817.

9. Azam Z, Shoaib M, Javed M, Sarwar MA, Shaikh H, Khokhar N. Initial results of efficacy and safety of Sofosbuvir among Pakistani Population: A real life trial - Hepatitis Eradication Accuracy Trial of Sofosbuvir (HEATS). Pak J Med Sci. 2017;33:48-52.

10. Iqbal S, Yousuf MH, Yousaf MI. Dramatic response of hepatitis C patients chronically infected with hepatitis $C$ virus genotype 3 to sofosbuvir-based therapies in Punjab, Pakistan: A prospective study. World J Gastroenterol. 2017;23:7899-7905.

11. loannou GN, Beste LA, Chang MF, Green PK, Lowy E , Tsui JI, Su F, Berry K. Effectiveness of sofosbuvir, ledipasvir/sofosbuvir, or paritaprevir/ritonavir/ombitasvir and dasabuvir regimens for treatment of patients with hepatitis $\mathrm{c}$ in the veterans affairs national health care system. Gastroenterology. 2016;151:457-471.

12. Gentile I, Borgia F, Buonomo AR, Castaldo G, Borgia G. A novel promising therapeutic option against hepatitis $C$ virus: an oral nucleotide NS5B polymerase inhibitor sofosbuvir. Curr Med Chem. 2013;20:3733-3742

13. Kwon HJ, Xing W, Chan K, Majka AN, Brendza KM, Kirschberg T, Kato D, Link JO, Cheng G, Liu X, Sakowicz R. Direct binding of ledipasvir to HCV NS5A: mechanism of resistance to an HCV antiviral agent. PLoS One. 2015;10:e0122844.

14. Varón A, Santos L, Tapias M, Cáez C, Marín JI, Santos O, Garzón M, Beltrán O, Gómez-Aldana A, Yepes IJ, Rondón M, Rosselli D. Colombian experience in the treatment of hepatitis $\mathrm{C}$ with directacting antiviral agents. Medicina (B Aires). 2019;79:29-36.

15. Sharafi H, Nikbin M, Alavian SH, Behnava B, Alavian SM. Efficacy and safety of generic Sofosbuvir/Ledipasvir fixed-dose combination in Iranian patients with chronic hepatitis $\mathrm{C}$ virus infection. Hepat Mon. 2017;17:e12216.

16. Liu CJ, Chuang WL, Sheen IS, Wang HY, Chen CY, Tseng KC, Chang TT, Massetto B, Yang JC, Yun C, Knox SJ, Osinusi A, Camus G, Jiang D, Brainard DM, McHutchison JG, Hu TH, Hsu YC, Lo GH, Chu CJ, Chen JJ, Peng CY, Chien RN, Chen PJ. Efficacy of Ledipasvir and Sofosbuvir treatment of HCV infection in patients coinfected with HBV. Gastroenterology. 2018;154:989-997.

17. Shousha HI, Akl K, Ragheb S, Medhat E, Esmat G. Generic Sofosbuvir/Ledipasvir for treatment of naïve, non-cirrhotic, easy to treat patients with chronic hepatitis $C$ genotype 4: 8 vs. 12 weeks of treatment. Hepat Mon. 2018;18:e78777.

18. Afdhal N, Reddy KR, Nelson DR, Lawitz E, Gordon SC, Schiff E, Nahass R, Ghalib R, Gitlin N, Herring R, Lalezari J, Younes ZH, Pockros PJ, Di Bisceglie AM, Arora S, Subramanian GM, Zhu Y, Dvory-Sobol H, Yang JC, Pang PS, Symonds WT, McHutchison JG, Muir AJ, Sulkowski M, Kwo P; ION-2 Investigators. Ledipasvir and sofosbuvir for previously treated HCV genotype 1 infection N Engl J Med. 2014;370:1483-1493.

19. Afdhal N, Zeuzem S, Kwo P, Chojkier M, Gitlin N, Puoti M, RomeroGomez M, Zarski JP, Agarwal K, Buggisch P, Foster GR, Bräu N, Buti M, Jacobson IM, Subramanian GM, Ding $X$, Mo H, Yang JC, Pang PS, Symonds WT, McHutchison JG, Muir AJ, Mangia A, Marcellin $\mathrm{P} ; \mathrm{ION}-1$ Investigators. Ledipasvir and sofosbuvir for untreated HCV genotype 1 infection. N Engl J Med. 2014;370:1889-1898.

20. Kowdley KV, Gordon SC, Reddy KR, Rossaro L, Bernstein DE, Lawitz E, Shiffman ML, Schiff E, Ghalib R, Ryan M, Rustgi V, Chojkier M, Herring R, Di Bisceglie AM, Pockros PJ, Subramanian GM, An D, Svarovskaia E, Hyland RH, Pang PS, Symonds WT, McHutchison 
JG, Muir AJ, Pound D, Fried MW; ION-3 Investigators. Ledipasvir and sofosbuvir for 8 or 12 weeks for chronic HCV without cirrhosis. N Engl J Med. 2014;370:1879-1888.

21. Shiha G, Esmat G, Hassany M, Soliman R, Elbasiony M, Fouad R, Elsharkawy A, Hammad R, Abdel-Razek W, Zakareya T, Kersey K, Massetto B, Osinusi A, Lu S, Brainard DM, McHutchison JG, Waked I, Doss W. Ledipasvir/sofosbuvir with or without ribavirin for 8 or 12 weeks for the treatment of HCV genotype 4 infection: results from a randomised phase III study in Egypt. Gut. 2019;68:721-728.

22. Mizokami M, Yokosuka O, Takehara T, Sakamoto N, Korenaga M, Mochizuki H, Nakane $K$, Enomoto $H$, Ikeda F, Yanase M, Toyoda $H$, Genda T, Umemura T, Yatsuhashi H, Ide T, Toda N, Nirei K, Ueno Y, Nishigaki Y, Betular J, Gao B, Ishizaki A, Omote M, Mo H, Garrison K, Pang PS, Knox SJ, Symonds WT, McHutchison JG, Izumi N, Omata M. Ledipasvir and sofosbuvir fixed-dose combination with and without ribavirin for 12 weeks in treatment-naive and previously treated Japanese patients with genotype 1 hepatitis C: an openlabel, randomised, phase 3 trial. Lancet Infect Dis. 2015;15:645653.

23. Bourlière $M$, Bronowicki JP, de Ledinghen $V$, Hézode $C$, Zoulim F, Mathurin P, Tran A, Larrey DG, Ratziu V, Alric L, Hyland RH, Jiang D, Doehle B, Pang PS, Symonds WT, Subramanian GM, McHutchison JG, Marcellin P, Habersetzer F, Guyader D, Grangé JD, Loustaud-Ratti V, Serfaty L, Metivier S, Leroy V, Abergel A, Pol S. Ledipasvir-sofosbuvir with or without ribavirin to treat patients with HCV genotype 1 infection and cirrhosis non-responsive to previous protease-inhibitor therapy: a randomised, double-blind, phase 2 trial (SIRIUS). Lancet Infect Dis. 2015;15:397-404.

24. Food\&Drug Administration. Hepatitis B and C treatments, date of access: 18 June 2019. access address https://www.fda.gov/ patients/hepatitis-b-c/hepatitis-b-and-c-treatments
25. Tao $T$, Jiang $X$, Chen $Y$, Song $Y$. Efficacy and safety of ledipasvir/ sofosbuvir with and without ribavirin in patients with chronic hepatitis $\mathrm{C}$ virus genotype 1 infection: a meta-analysis. Int $\mathrm{J}$ Infect Dis. 2017:55:56-71.

26. Guerra I, Marie L, Cure S. Long-term outcomes of ledipasvir/ sofosbuvir (LDV/ SOF) for the treatment of chronic hepatitis c infected $(\mathrm{HCV})$ genotype 1 patients in the UK. Value Health. 2014;17:A675

27. Cure S, Guerra I. Cost-effectiveness and long-term outcomes of sovaldi (SOFOSBUVIR) for the treatment of chronic hepatitis c infected (HCV) patients from a Swedish societal perspective. Value Health. 2014;17:A675

28. Beinhardt S, Al-Zoairy R, Kozbial K, Stättermayera F, Maieron A, Stauber R, Strasser M, Zoller H, Graziadei I, Rockenschaub SR, Trauner M, Ferenci P, Hofer H. Long-term follow-up of ribavirinfree DAA-based treatment in HCV recurrence after orthotopic liver transplantation. Liver Int. 2018;38:1188-1197.

29. Cieciura T, Hryniewiecka E, Foroncewicz B, Strzelczyk Z, Ciszek M, Paczek L. Long-term follow-up of liver transplant recipients treated with direct-acting antiviral agents for hepatitis $c$ recurrence after transplantation. Transplant Proc. 2020;52:2468-2471.

30. Idilman R, Demir M, Aladag M, Erol C, Cavus B, Iliaz R, Koklu H, Cakaloglu Y, Sahin M, Ersoz G, Koksal I, Karasu Z, Ozgenel M, Turan I, Gunduz F, Ataseven H, Akdogan M, Kiyici M, Koksal AS, Akhan S, Gunsar F, Tabak F, Kaymakoglu S, Akarca US; Early Access Program (EAP) Study Groupa. Low recurrence rate of hepatocellular carcinoma following ledipasvir and sofosbuvir treatment in a real-world chronic hepatitis C patients cohort. J Viral Hepat. 2019;26:666-674. 